\title{
Environmental management and product innovation: The moderating role of the dynamic capability of small manufacturing firms
}

\begin{abstract}
Given the overwhelming concerns on environmental issues, our study attempts to investigate the important role of environmental management practice in the context of product exploration and product exploitation. Additionally, we examine the moderating effect of transformative capability and absorptive capability on the relationship between environmental management and product exploration and exploitation. Based on a survey of 106 managerial-level employees from small manufacturing firms in the United Kingdom (UK), this study found that environmental management practice has a positive direct effect on product exploitation and product exploration. The study also found that (1) transformative capability positively influences the relationship between environmental management and product exploration; (2) absorptive capability negatively influences the relationship between environmental management and product exploitation. From this study, we offer novel insights that extend the existing literature concerning the outcomes of environmental management within the context of product exploration and product exploitation.
\end{abstract}

Keyword: environmental management, sustainability, small firms, dynamic capability, exploration, exploitation. 


\section{Introduction}

This study aims to extend the understanding about the relationship between environmental management and product innovation in the context of small manufacturing firms. While there have been sporadic efforts to address these issues, environmental management and product innovation have their own research streams and the knowledge in both have been developed separately (De Medeiros et al., 2014). Though some studies (e.g. Maletič et al., 2016; 2018) have recently attempted to create a linkage between these two streams of research, studies have tended to remain at a conceptual level; hence the need for more empirical evidence to unify the current understanding from studies focusing on environmental management and product innovation.

As a response to the research gap on the role of environmental management, this study addresses the following research questions: How does environmental management impact on product innovation? And, what effect does dynamic capability have on the relationship between practising environmental management and product innovation? These research questions are derived from the inherent conundrum associated with the need to respond to the current awareness concerning sustainability, at the same time as overcoming a challenge to introduce environmental management as a part of the product development process (Aragón-Correa and Sharma, 2003; Triguero et al., 2013). More specifically, this study is a response to the recent call (e.g. Boiral et al., 2018; Maletič et al., 2016; 2018) for studying the practice of environmental management in a small firm context. The implementation of environmental management is a challenge for small firms as they have limited access to resources and are bounded to their local context (Bromiley and Rau, 2016). Considering the limitations on small firms, this study argues that the success of introducing environmental management into product innovation is contingent on the capability to dynamically integrate, build and reconfigure 
internal and external resources to address rapidly changing environments (Aboelmaged and Hashem, 2019; Ferreras-Méndez et al., 2016; Gebauer et al., 2012; Teece et al., 1997).

Using a survey conducted among 106 managerial-level employees from small manufacturing firms in the UK, this study intends to make several contributions. First, it provides insights into the practice of environmental management in the context of small manufacturing firms. Small firms are important and considered to be the cornerstone of sustainable development (Blackman, 2006), representing around ninety-nine percent of all enterprises (Van Hoof and Lyon, 2013). While previous literature has investigated the practice of large firms, only a few have focused on small manufacturing firms, creating a paucity in understanding about the interaction among environmental management, innovation and the dynamic capability of small firms. Second, following recent calls (e.g. Boiral et al., 2018; Maletič et al., 2016; 2018; Ogbeibu et al., 2019; Ambec and Lanoie, 2008), this study examines the impact of environmental management on small firms' innovation activities. To be more specific, we advance current and existing works by focusing on the role of dynamic capability in moderating the relationship between environmental management and product innovation. This effort is an extension of the emerging debate in the literature on environmental management and innovation initiated by several scholars such as Maletič et al. $(2016 ; 2018)$ and Ogbeibu et al. (2019). Third, this study helps advance both practice and research. From a practice perspective, it provides insights for small firm managers about environmental management practice, producing competitive advantage, and developing environmentally-friendly products. From a research perspective, it seeks to advance the theoretical linkages between environmental management and innovation management. The study also provides underpinnings for further exploration regarding the role of dynamic capability in supporting the efforts of small firms in addressing sustainability and environmental issues. 
The paper is organised as follows. We start by discussing the definition and theoretical background. Next, we hypothesize about the impact of environmental management on product innovation and the role of dynamic capability in moderating the relationship between the two. The following section is concerned with methodological aspects of the empirical study, including data collection, measurement issues and method of analysis. Descriptive results and modelling results are presented and discussed next. The paper closes with a conclusion, implications and limitations.

\section{Theoretical background}

\subsection{Defining environmental management and product innovation}

The cleaner production literature shows that environmental management is a structured and systematic approach for managing and measuring organisational environmental impacts (Xie et al., 2016b). In this study, environmental management practices are defined as actions taken by organizations, including formal standards and common practices, aimed at reducing the negative impact on the natural environment. The activities involve multiple functional units across the firm, namely logistics, operations, marketing and services. In the past, environmental management has naturally been applied during production processes (Prajogo et al., 2014; Albino et al., 2012), but it has been extended to other processes such as marketing and new product development. It involves the creation of new routines as well as re-alignment with existing operational routines aimed at reducing the impact on the natural environment (Diwekar and Shastri, 2010). The benefits from implementing environmental management have been discussed in previous studies and include new business opportunities (Montabon et al., 2007), an increase in financial performance (O'Donohue and Torugsa, 2016) and a decrease in negative environmental impacts (Ateş et al., 2012; Molina-Azorín et al., 2009). 
Due to the rise in popularity of environmental management, more businesses are aware of environmental consequences during the product development process (Chen, 2011); consumers are more prone to purchase products that consider the environment and sustainability (Makower, 2009) and are more willing to pay a premium price in supporting sustainable efforts (Chen and Chang, 2012). While the common arguments suggest that firms need to create products with core attributes that satisfy customer's needs, there has been a rise in demand for products with eco-friendly benefits (Zhang et al., 2015) and especially those which have a less negative impact on the environment (Beylot et al., 2019). This situation has encouraged firms to integrate an environmental philosophy with product innovation, the aim being to prevent production waste while increasing efficiencies.

As there has been increased attention toward assimilating environmental management into innovation activity, especially during new product development, this study responds to that call by examining two types of product innovation activities, namely product exploration and product exploitation (Chan et al., 2016; Severo et al., 2017; Voss et al., 2008). Product exploration is defined as the extent to which firms introduce new products to meet emerging customers' demand, meet new market potential or promote the introduction of new technology in products or services. In contrast Product exploitation is the extent to which firms emphasize incremental innovation of products and designs to meet the needs of existing customers (Jansen et al., 2006). The effort is to expand, refine or improve the existing offering. While early studies have argued that balancing these two activities is difficult, further studies have identified the existence of ambidextrous organisations that can perform both (Kammerlander et al., 2015). However, since the sustainability issues are becoming mainstream, it is important for firms to 
integrate environmental management practices with both innovation activities (Pujari et al., 2003).

\subsection{Environmental management, product innovation and dynamic capability}

For many small manufacturing firms, capability in linking existing skills and resources to meet external pressures, such as sustainability and environmental awareness, is a key success in supporting growth through innovation (Dunlap et al., 2016). Compared to large firms, small firms experience limited resources which may reduce their ability to introduce environmental management into innovation activities. However, such firms are known to be more flexible and agile in transforming and reconfiguring resources. As a result, small firms' capabilities are considered to be the catalyst for practising environmental management. This is in line with the contingency perspective that believes that small firms' actions or strategies need to fit within their context - whether it is the external environment, organisational structure, or precondition factors (Mokhtar et al., 2016). In this case, the implementation of environmental management into innovation activities should be aligned with small firms' capability in order to maximise the outcomes. The capability to dynamically integrate, build and reconfigure internal and external resources and skills to address a rapidly changing environment is critical (Winter, 2003; Eisenhardt and Martin, 2000; Teece et al., 1997). Given that applying environmental management and innovation involves a high degree of change and uncertainty, dynamic capabilities can be treated as a moderator for ensuring the positive impact of environmental management on product innovation activities.

The notion of dynamic capabilities was first introduced by Teece et al. (1997) to describe competitive advantage in dynamically changing markets. It was initially defined as the capacity of an organization to purposefully create, extend, or modify its resource base (Teece, 2007). In 
understanding the green entrepreneurial orientation, Jiang et al. (2018) described dynamic capability as a mechanism to exploit new ideas and encourage innovativeness. As discussed in Horbach et al. (2012) and Aldieri et al. (2019), innovation as a part of environmental management can be identified as: (a) market pull factors where the market demands a 'green' product and process, (b) technology push drivers where firms have explored new technology to make a product or process 'greener', and (c) regulation to meet certain requirements for environmental performance. All those factors require firms to dynamically develop their capability. This includes the capability to acquire, develop and reconfigure resources or knowledge from internal and external sources. In line with the above argument, this study considers that small firms' capability is referred to as transformative and absorptive. Transformative capability refers to the degree of a firm's ability to constantly redefine a portfolio of product or service opportunities based on knowledge endogenous to the firm. The term was initiated from Garud and Nayyar (1994) (as transformative capacity) while referring to the exploitation of knowledge generated within an organisation to create technological advances, new business opportunities, and increase competitive advantages. Absorptive capability refers to the degree of a firm's ability to recognize the value of new, external information, assimilate it, and apply it to commercial ends (Cohen and Levinthal, 1990). It involves the assimilation process of new external knowledge with the firm's existing internal knowledge (Wang et al., 2015). In short, transformative capability is defined as a firm's capability to utilise internal resources and knowledge while absorptive capability is the capability of firms to absorb new external resources and knowledge. Figure 1 shows the hypothetical model of this study.

Figure 1. Research framework and hypothetical relationships 


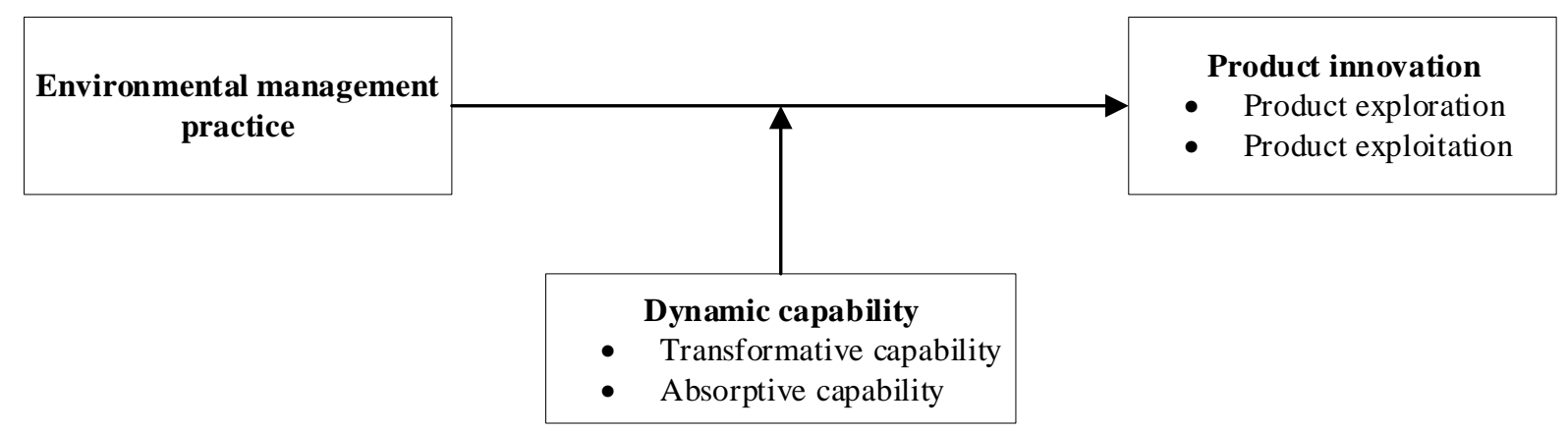

\subsection{Hypothesis development}

\subsubsection{The impact of environmental management practice on product innovation}

The first hypothesis concerns the influence of environmental management on product exploration and product exploitation. Several studies (e.g. Maletič et al., 2018; Chen and Chang, 2013) have argued that environmental management practice supports product exploration. Recent findings have shown that performing exploration can be used as a predictor of innovation performance especially in competitive environments (Maletič et al., 2018). One of the reasons is that exploration is driven by desires to discover something new (Yalcinkaya et al., 2007); and exploration in environmental management has a long-term objective of producing new products that have the least negative impact on the environment (De Medeiros et al., 2014). Thus, environmental management drives small firms to realign their strategy to explore new products while at the same time focusing on emerging new customers and market needs (Molina-Castillo et al., 2011; Molina-Azorín et al., 2009). Another reason relates to the reduction of daily operating costs as a result of the implementation of environmental management. In addition, environmental management practices usually force firms to explore new areas of research and technology. This sustainability issue has attracted more firms to develop new products with "green" features as it is becoming a powerful competitive weapon in the market (Chen, 2011). For instance, many car manufacturers have advanced technology 
by producing car engines with cleaner combustions and better fuel economy. Based on these arguments, we posit as follows:

Hla. Environment management practice has a positive impact on product exploration activities.

Moreover, environmental management may encourage innovation through product exploitation activities. With product exploitation, firms perform innovation activities through incremental improvements such as the introduction of product variants featuring improvements and market repositioning (Levinthal and March, 1993; Stone, 2006) while trying to reduce usage in materials, water and energy use (Maletič et al., 2016). Performing exploitation does not only strengthen a small firm's position in the market but is also more likely to reduce the cost of operation so lower prices can be offered to consumers (Prajogo, 2016). As the objective is to consider the reduction of natural resources, water, energy, materials and other practices that minimises the negative impact on the environment (Potts, 2010), among the possible solutions are improved products that offer sustainable features such as having recycled components, less packaging, being manufactured in an energy-conserved way, and being less detrimental to human health (Ikram et al., 2019). When small firms implement environmental management, they potentially optimise the production process and therefore stimulate exploitation activities (Shin et al., 2008). Hence, product exploitation can be an option for small firms to achieve their environmental goals. In other words, small firms practising environmental management are more likely to perform incremental innovation and improve their existing product(s). Based on the above arguments, we suggest that a higher level of environmental management practices would result in more encouragement to perform product exploitation. Therefore, the hypothesis is constructed as follows: 
H1b. Environmental management practice has a positive impact on product exploitation activities.

\subsubsection{Transformative capability and its moderating role in environmental management and product innovation practices}

This hypothesis argues that transformative capability is critical for the implementation of environmental management on small firm product innovation. Small firms should develop transformative capability so they can adapt their business according to the market's need and expectation such as the increasing awareness of sustainability and the environment (Wang et al., 2015). Transformative capability is an extension of dynamic capability and it explains the process of utilising internal resources to meet external demand. The transforming aspect of dynamic capabilities is needed most obviously for addressing new opportunities such as new products produced with stronger environmental awareness (Dangelico et al., 2017).

Transformative capability encourages the use of internal knowledge to trigger the development of new knowledge while trying to optimise existing knowledge (Pandza and Holt, 2007). A study from Nath and Ramanathan (2016) shows that the ability to integrate internal knowledge is critical to support environmental management practice and to produce strong environmental performance. Several studies (e.g. Albino et al., 2012; Dibrell et al., 2011) found a critical condition for transformative capability is the presence of commitment and strong collaboration among units within a firm. This is so due to time saving advantages, for example not needing to "break the ice", and understanding of the social cognition of each unit. In the context of product exploration, those conditions will help firms to utilise internal resources and knowledge as a response to environmental changes. These activities often focus on exploring new opportunities such as the development of new technology or the opening of a new market 
as a result of new trends and perspectives to preserve the environment and increase sustainability. In line with the above arguments, we propose the hypothesis as stated below:

H2a. The interaction between transformative capability and environmental management practice produces a positive impact towards product exploration activities.

Similarly, transformative capability helps small firms in exploiting their current product or market. An example of a firm's transformative capability is the integration of different functional units within an organisation which can produce internal knowledge integration that is important for firms engaging in green practices (Dibrell et al., 2011). One reason for this is that integration of different functional units brings a different composition and level of heterogeneity (Bercovitz and Feldman, 2011). During product exploitation, small firms perform activities to increase efficiency of the production process while introducing environmental management practices. During the process, the capability to reconfigure existing resources and knowledge is critical to deliver the innovation within environmental management practice. In summary, combining internal resources and knowledge with understanding of the current market means small firms will be able to respond to the increased awareness of environmental performance through product exploitation. Thus, the following hypothesis is considered:

H2b. The interaction between transformative capability and environmental management practice produces a positive impact towards product exploitation activities.

\subsubsection{Absorptive capability and its moderation role in environmental management and} product innovation practices 
This study argues that small firms' absorptive capability helps to strengthen the implementation of environmental management on innovation activities (Wang and Ahmed, 2007). Absorptive capability appears to be one of the important determinants of a firm's capability to absorb new external knowledge and to apply it to create commercial goals (Açikgöz et al., 2016). Studies have suggested that absorptive capability can assist businesses to capitalise on external sources of innovation (West and Bogers, 2014; Harrington and Guimaraes, 2005). In order to respond to the needs of the market, small firms respond by introducing new products or improvement (e.g. upgrade, update) to existing products that create less environmental damage (e.g. avoiding production wastage) (De Medeiros et al., 2014; O’Cass et al., 2014).

Firms with a high level of absorptive capability are potentially more likely to assist environmental management in succeeding with product exploration. With respect to green practices, as firms increase their effort to explore new products with sustainable features, they usually engage with new buyers and regulatory authorities, and gain new external knowledge which provides advantages to explore new product opportunities (Xie et al., 2016a). The essence of product exploration by "experimentation with new alternatives" is prone to be complex and involve uncertain returns (Zhang et al., 2015; March, 1991). Absorptive capability is known to enhance speed and frequency of innovation and knowledge that it produces (Lane et al., 2006). The resulting knowledge databases and unique competitive edges helps to serve the firm in exploring innovation in new product ventures that support environmental practices (Pacheco et al., 2018). This element is needed in the product exploration strategy since firstmovers tend to have more opportunity. Using the advantage of early access to knowledge, firms can plan their exploration strategy more efficiently. Thus, we posit the hypothesis as follows:

H3a. Interaction between absorptive capability and environmental management practice produces a positive impact on product exploration activities. 
While the essence of product exploration is "experimentation with new alternatives" (Zhang et al., 2015; March, 1991), product exploitation aims to develop a more efficient use of organizational resources and reduce development time and costs (Jansen et al., 2006). For product exploitation, absorptive capacity provides knowledge about integrating environmental management practices into existing products or processes. Firms engaging in exploitation opportunities usually interact with outsiders (Foss et al., 2013) to obtain a more accurate and complete assessment of what the markets need to avoid unwanted and unimportant features (Carbonell et al., 2009). It provides the advantage of an expanded range of resources beyond a firm's internal capacity to create solutions for customer needs (Salonen and Jaakkola, 2015). This kind of external collaboration is therefore important for firms practicing environmental management in order to have a better understanding of other competitors' practices and current market needs, which provides a better insight into the appropriate refinement of the existing product. As absorptive capability helps firms to develop and maintain external networks, firms with a high level of absorptive capability are more likely to absorb information and knowledge about environmental management and quickly build their capability (Xie et al., 2016a). Building on the above discussion, the following hypothesis is posited:

H3b. Interaction between absorptive capability and environmental management practice produces a positive impact on product exploitation activities.

\section{Research Methods}

\subsection{Research Setting and sample}

The empirical research was conducted based on a survey of UK small manufacturing firms. We defined small manufacturing firms as having an annual turnover of less than $£ 25$ million and/or having fewer than 250 employees (Department for Business Innovation \& Skills, 2012). 
The FAME (Financial Analysis Made Easy) database was used to retrieve the list of manufacturers in the UK (Story et al. 2015; Deutz et al. 2013). We approached respondents from various backgrounds ranging from environmental managers to firm CEOs. In cases where no specific position was appointed to manage a firm's environmental activity, we asked for suitable respondents at managerial levels that would have access to the information that we required.

Before conducting the survey, we conducted a pilot interview among random business owners or top management representatives of small manufacturing firms. In total, we conducted pilot interviews with seven firms. The respondents were asked to complete the online questionnaire and to indicate any ambiguous or unclear phrasing of items. Besides answering the survey, respondents were also asked to provide suggestions to improve it. After completing the pilot test, we improved the questions and produced the final questionnaire. We employed simple random sampling where 2,767 small manufacturing firms were contacted by phone between August 2016 and December 2016. To ensure respondents were comfortable answering the survey questions, we guaranteed anonymity (López-Gamero and Molina-Azorín, 2016). The firms that agreed to participate in the research were given a special link created specifically for that particular firm. Follow-up phone calls were made two weeks after sending the survey. Finally, 106 firms completed the survey giving a response rate of 5.6\%. We benchmarked our response rate with previous studies from the same domain and found ours comparable to similar survey-based research (e.g. Gualandris and Kalchschmidt, 2016; Jabbour et al., 2014; Mitra and Datta, 2014). The demographical profile of the firm sample is presented in Table 1.

Table 1. Firm Profiles

\begin{tabular}{llc}
\hline Demographics & $\begin{array}{c}\text { Number of } \\
\text { respondents }\end{array}$ & $\%$ \\
\hline
\end{tabular}




\begin{tabular}{|c|c|c|}
\hline \multicolumn{3}{|l|}{ Type of business } \\
\hline Chemical / pharmaceutical & 4 & 3.8 \\
\hline Electrical / medical equipment / communication equipment & 13 & 12.3 \\
\hline Paper / textile / printing / leather & 12 & 11.3 \\
\hline Food & 8 & 7.5 \\
\hline Furniture / wood / rubber / plastic product & 10 & 9.4 \\
\hline Metal / machine / steel & 22 & 20.8 \\
\hline Other $(\mathrm{s})$ & 7 & 6.6 \\
\hline Multiple industries & 30 & 28.3 \\
\hline \multicolumn{3}{|l|}{ Age of firm } \\
\hline Less than 10 years & 4 & 3.8 \\
\hline $11-25$ years & 20 & 18.9 \\
\hline $26-50$ years & 47 & 44.3 \\
\hline $51-100$ years & 24 & 22.6 \\
\hline More than 101 years & 11 & 10.4 \\
\hline \multicolumn{3}{|l|}{ Number of employees } \\
\hline Less than 25 & 13 & 12.3 \\
\hline $26-50$ & 23 & 21.7 \\
\hline $51-100$ & 37 & 34.9 \\
\hline $101-250$ & 33 & 33.1 \\
\hline \multicolumn{3}{|l|}{ Sales } \\
\hline Less than $£ 1,000,000$ & 3 & 3 \\
\hline$£ 1,000,001-5,000,000$ & 21 & 21.2 \\
\hline$£ 5,000,001-10,000,000$ & 26 & 26.3 \\
\hline$£ 10,000,001-25,000,000$ & 49 & 49.5 \\
\hline
\end{tabular}

We performed some analysis regarding the collected date. The completed surveys were compared with the non-completed surveys with respect to the dependent variable to test the existence of mean difference. The results from the paired sample t-test showed no significant statistical difference between both categories at the significance level of 0.05 , indicating absence of non-response bias (Wang and Ahmed, 2007). We acknowledge that common method bias is a source of threat since our survey was responded to by a single respondent from each firm. As suggested by Podsakoff and Organ (1986), Harman's single factor test was employed to detect common method bias. The test was conducted via principle component analysis with varimax rotation. Four factors (eigenvalue>1) emerged totalling $83.28 \%$ of 
variance explained with no one factor accounting for more than $50 \%$ of the variance (Mattila and Enz, 2002).

\subsection{Measurement and validation of constructs}

Using a 7-point Likert scale ranging from 1 for "strongly disagree" to 7 for "strongly agree", all items in the questionnaire were measured from a firm-level perspective and were treated as reflective indices. The complete items can be found in the appendix.

Product exploration $(\alpha=.88)$ was measured using four items from Jansen et al. (2006), capturing the extent to which new products are introduced to meet market demands.

Product exploitation $(\alpha=.93)$ is the extent to which firms emphasize incremental innovation towards existing products and was measured using four items adapted from Jansen et al. (2006). Environmental management $(\alpha=.89)$ was examined by employing a five-item scale of environmental management adapted from Porter's (1985) value chain model. We asked respondents to rate the development of environmental management at their organisation in five areas: inbound logistics, outbound logistics, operations, marketing and sales, and services. We treated this construct as a formative measure.

Transformative capability $(\alpha=.95)$ was measured with an existing 5-item scale from Gibson and Birkinshaw (2004) and Schilke (2014). Respondents were asked to rate their firm's ability to strategically adapt opportunities and knowledge within the firm.

Absorptive capability $(\alpha=.95)$ used a four-scale measure adapted from García-Morales et al. (2008). Respondents were asked to rate their firm's ability to recognise new external opportunities and knowledge to undertake internal transformation.

Several control variables were selected based on previous literature and the perception that they would affect the firm's environmental management and innovation activities. These were the 
firm's total years of operation, number of employees and annual sales. These variables were normalised using natural logarithm alleviate univariate non-normalities and account for nonlinear effects (Feng et al., 2010; Swamidass and Kotha, 1998).

\section{Findings}

\subsection{Descriptive statistics and factor analysis}

The study employed factor analysis to reduce the items. To measure the reliability, the KaiserMeyer-Olkin Test was performed. The result show that the sampling adequacy is 0.873 indicating reliability of the model. The constructs with eigenvalues of more than 1 represented $83.28 \%$ of variance explained. The Cronbach alpha had values higher than 0.7 (minimum=0.844) showing internal consistency among the constructs (Nunnally and Bernstein, 1994). The factor loading of items within the constructs had a minimum value of 0.666. Higher loading scores for the items is important and have a greater influence to present a factor (Hair et al., 2006). Moreover, confirmatory factor analysis was employed to establish convergent validity and discriminant validity (Fornell and Larcker, 1981). For convergent validity, this study followed the work of Mitra and Datta (2014) where average variance extracted (AVE) should be at least 0.5 and composite reliability (CR) is above 0.7 . The model was an overall fit where none of the items from the constructs needed to be removed. The minimum AVE was 0.666 and 0.887 for CR. For discriminant validity, following Fornell and Larcker (1981), an inter-construct correlation was conducted (Table 2). The result shows that the square root of AVE for each construct exceeded the correlation value between the two. Upon assessing the goodness-of-fit for our model, we confirmed that the model displayed an

overall fit $\left(\mathrm{X}^{2}=1.77 ; \mathrm{GFI}=.82 ; \mathrm{AGFI}=.95 ; \mathrm{RMSEA}=.09\right)$. Table 3 shows the construct and items representing the whole research model along with the item loadings, AVE and CR. 
Table 2. Descriptive statistics and correlation coefficients

\begin{tabular}{lllllllll}
\hline & Mean & SD & 1 & 2 & 3 & 4 & 5 & 6 \\
\hline Product exploration & 5.13 & 0.13 & 1 & & & & & \\
Product exploitation & 5.52 & 1.16 & $.57^{* *}$ & 1 & & & & \\
$\begin{array}{l}\text { Environmental } \\
\text { management }\end{array}$ & 20.12 & 7.61 & $.30^{* *}$ & $.32^{* *}$ & 1 & & & \\
$\begin{array}{l}\text { Absorptive capability } \\
\text { Transformative }\end{array}$ & 4.94 & 1.29 & $.32^{* *}$ & $.29 * *$ & .17 & 1 & & \\
capability & 4.33 & 1.52 & $.36^{* *}$ & $.35^{* *}$ & $.58^{* *}$ & $.53^{* *}$ & 1 & \\
Years of operation & 51.04 & 40.06 & .08 & -.01 & .13 & .14 & .07 & 1 \\
\hline $\mathrm{N}=106 ; * \mathrm{p}<0.05 ; * \mathrm{p}^{*}<0.01$ & & & & & & & &
\end{tabular}

Table 3. Summary of measurement scales

\begin{tabular}{|c|c|c|c|c|c|}
\hline Items & Mean & SD & $\begin{array}{c}\text { Item } \\
\text { loading }\end{array}$ & $\begin{array}{l}\text { Composite } \\
\text { Reliability }\end{array}$ & AVE \\
\hline Transformative capability & & & & 0.95 & 0.80 \\
\hline $\mathrm{T} 1$ & 4.29 & 1.68 & 0.84 & & \\
\hline $\mathrm{T} 2$ & 4.36 & 1.65 & 0.88 & & \\
\hline $\mathrm{T} 3$ & 4.43 & 1.69 & 0.92 & & \\
\hline $\mathrm{T} 4$ & 4.41 & 1.70 & 0.89 & & \\
\hline T5 & 4.16 & 1.60 & 0.81 & & \\
\hline Absorptive capability & & & & 0.95 & 0.84 \\
\hline A1 & 5.00 & 1.43 & 0.90 & & \\
\hline $\mathrm{A} 2$ & 4.99 & 1.33 & 0.90 & & \\
\hline A3 & 4.97 & 1.31 & 0.90 & & \\
\hline A4 & 4.78 & 1.43 & 0.84 & & \\
\hline Product exploration & & & & 0.89 & 0.68 \\
\hline $\mathrm{P} 1$ & 5.30 & 1.44 & 0.64 & & \\
\hline $\mathrm{P} 2$ & 5.24 & 1.67 & 0.85 & & \\
\hline $\mathrm{P} 3$ & 5.18 & 1.61 & 0.89 & & \\
\hline $\mathrm{P} 4$ & 4.79 & 1.68 & 0.81 & & \\
\hline Product exploitation & & & & 0.93 & 0.78 \\
\hline R1 & 5.39 & 1.28 & 0.83 & & \\
\hline $\mathrm{R} 2$ & 5.66 & 1.23 & 0.87 & & \\
\hline R3 & 5.53 & 1.32 & 0.88 & & \\
\hline $\mathrm{R} 4$ & 5.52 & 1.25 & 0.86 & & \\
\hline Environmental management & & & & 0.88 & 0.67 \\
\hline $\mathrm{E} 1$ & 3.67 & 1.80 & 0.89 & & \\
\hline E2 & 4.85 & 1.78 & 0.77 & & \\
\hline E3 & 3.95 & 1.85 & 0.84 & & \\
\hline E4 & 3.76 & 1.83 & 0.83 & & \\
\hline E5 & 3.89 & 1.83 & 0.86 & & \\
\hline
\end{tabular}

Note: SD, standard deviation. 


\subsection{Analysis}

In this study, a hierarchical regression method was employed (Ferreras-Méndez et al., 2016). To detect any multicollinearity issues, two indicators were used, namely correlation between variables and the variance inflation factor (VIF). The highest correlation was 0.57 while the results show no VIF's higher than 2.14. Both results show that the analysis has no issue with multicollinearity. Hierarchical regressions were conducted in five steps. In the first step, the control variables were introduced, and the main effects were examined in the second step. The remaining steps were used to investigate the moderation effect. The overall results of the regression analysis are displayed in Table 4 which shows that control variables were not significant across the models. Hence, the number of years firms had been operating, number of employees in the firm, and firm accumulated sales has no effect on product exploitation and product exploration.

With regard to the effect of environmental management on product exploration and product exploitation, the analysis shows a mixed result. Models 3, 5, 7, 8 and 10 show a positive and significant relationship $(\mathrm{P}<0.05)$, while models 2,4 and 9 show no significant relationship between environmental management and product exploration/exploitation. This supports hypothesis $1 a$ and hypothesis $1 b$. On the one hand, the finding supports the role of environmental management on product exploration. As Prajogo et al. (2014) argue, environmental management involves a production process that relates to all aspects of product manufacturing, usage, handling, logistics and waste management, the most probable outcome is the creation of new products or refinement of existing products that abide by the environmental concerns at every step of the value chain. On the other hand, the findings also support the influence of environmental management on product exploitation. The reason is that product exploitation offers the quickest and easiest way to support environmental initiatives 
(Maletič et al., 2014). As practicing such a strategy may jeopardise the profitability, firms try to introduce environmental concerns through improvement of an existing product (Pujari et al., 2003). In this case, product exploitation may occur through minimising by-product waste and increasing the use of recycled material on some aspects of the existing product (Lenox et al., 2000). Overall, the findings support the recent argument from Wang et al. (2019) that a firm's environmental culture and practice are the main elements of green innovation.

The next analysis dealt with the interaction between the variables of environmental management and dynamic capabilities. To check whether transformative capability has a moderating effect on the connection between environmental management and product exploration, we observe the difference of an adjusted $\mathrm{R}^{2}$ for the model without moderating effects (model 2) compared to the adjusted $\mathrm{R}^{2}$ of the model with moderating effects (models 3 and 5). The table shows higher explanatory power in models 3 and 5 compared to model 2 . Besides that, the moderating effect of transformative capability is significant and positive in both models 3 and 5 proving that the interaction between environmental management and transformative capability is significant. The finding confirms hypothesis $2 a$ that transformative capability strengthens the impact of environmental management on product exploration. This finding is in agreement with prior research that supports the positive impact of internal knowledge acquisition and utilisation on firm performance (Wang et al., 2015) and innovativeness (Jiang et al., 2018) . In line with the concept of dynamic capability, having transformative capability promotes the combination of internal resources in the development of new products (Teece, 2016). Unfortunately, the findings failed to confirm any support for the argument that transformative capability moderates the relationship between environmental management and product exploitation. The results were insignificant based on models 8 and 10 for such a relationship. Before adding the interaction effect (model 7), the adjusted $\mathrm{R}^{2}$ was 
$13.9 \%$ but after including the interaction effect (model 10), the explanatory power dropped to $13.1 \%$. Thus, hypothesis $2 b$ was not supported, as the result suggests transformative capability has no moderating effect on the connection between environmental management and product exploitation. One explanation might be due to the nature of product exploitation itself that is associated with an incremental innovation and a well-defined return (Yang et al., 2014). The process might not require integration with existing knowledge to proceed such a strategy as compared to a product exploration strategy which involves higher uncertainty due to its more radical innovation (Maijanen and Virta, 2017). While this result in insignificant, it enhances the dynamic capability literature to argue that not all aspects of dynamic capability are able to influence firm innovation strategy.

The next analysis concerned the interaction effect of environmental management and absorptive capability. The findings (models 3 and 4) suggest that the interaction effect does not influence product exploration. Therefore, we could not support Hypothesis 3a. This result seems to indicate that, among small manufacturing firms, resources and knowledge gained from transformative capability may play a more important role in determining a firm's environmental management practice with regard to product exploration than knowledge gained from absorptive capability. Interestingly, the finding (models 8 and 9) suggests that the interaction between environmental management and absorptive capability has a negative impact on product exploitation $(\mathrm{P}<0.05)$, which supports hypothesis $3 b$. One explanation could be that collaborating with external organisations to absorb new knowledge and resources exposes risks of technology leakage and also incurs a higher cost due to the collaboration process (Chen et al., 2011). Though dynamic capabilities are viewed as an enabler towards the success of organisations during changing circumstances (Helfat and Winter, 2011), having the capacity to value external knowledge and ability to leverage it (i.e. absorptive capability) 
(Ferreras-Méndez et al., 2016) may not help to complement processes of product refinement and instead potentially disturb the current focus of the organisation.

Figure 2 illustrates the role of dynamic capability in moderating the relationship between environmental management and product innovation using a simple slope analysis (Aiken et al., 1991). In the figure, the dependent variables are placed on the vertical axis while the independent variable is shown along the horizontal axis. Panel $\mathrm{A}$ in figure 2 depicts the interaction between transformative capability and environmental management on product exploration. When transformative capability is available to firms, environmental management has a positive effect on product exploration. Moreover, it also reveals that the impact of environmental management on product exploration decreases for firms with a low level of transformative capability. Panel B in figure 2 visualises the pattern of interaction between environmental management and absorptive capacity. The findings failed to identify a positive interaction between environmental management and product exploitation. In other words, when a firm's absorptive capability is low, its practice of environmental management leads to a stronger positive effect on product exploitation compared to when a firm's absorptive capability is high. 
Table 4 Result of hierarchical regression

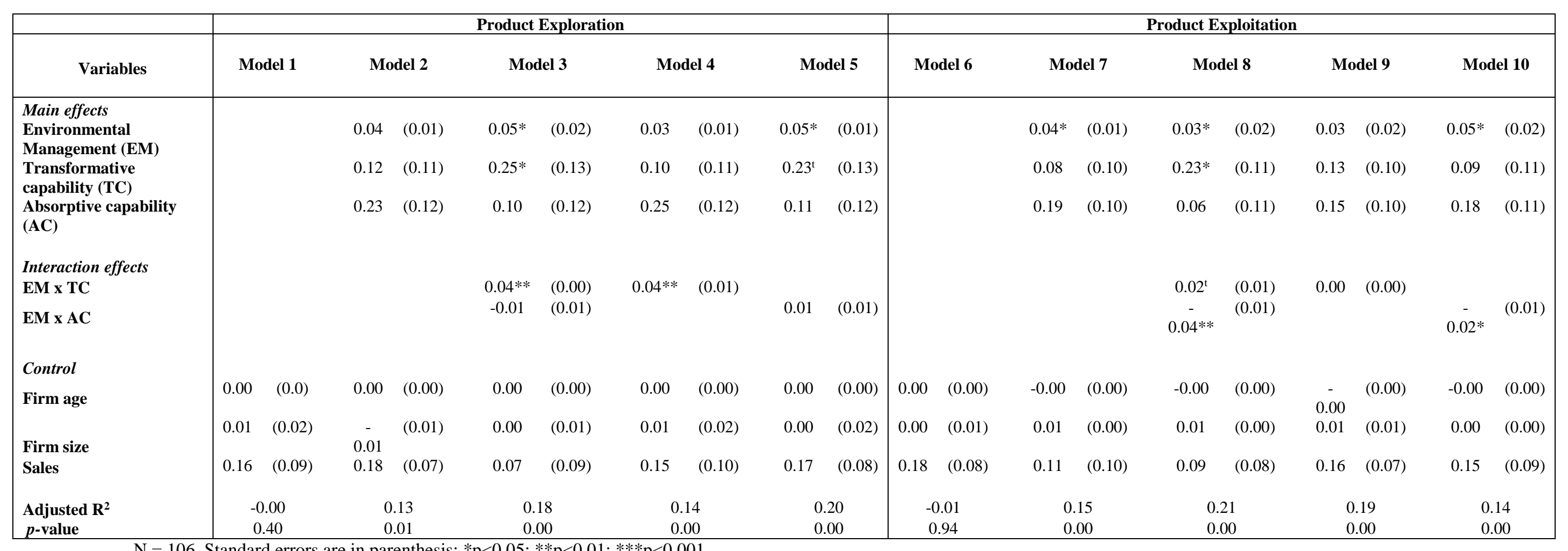

$\mathrm{N}=106$. Standard errors are in parenthesis; ${ }^{*} \mathrm{p}<0.05 ;{ }^{*} \mathrm{p}<0.01 ; * * * \mathrm{p}<0.001$ 
Figure 2. Plotting Significant Two-way Interactions

Panel A: Product Exploration = environmental management $\mathrm{x}$ transformative capability

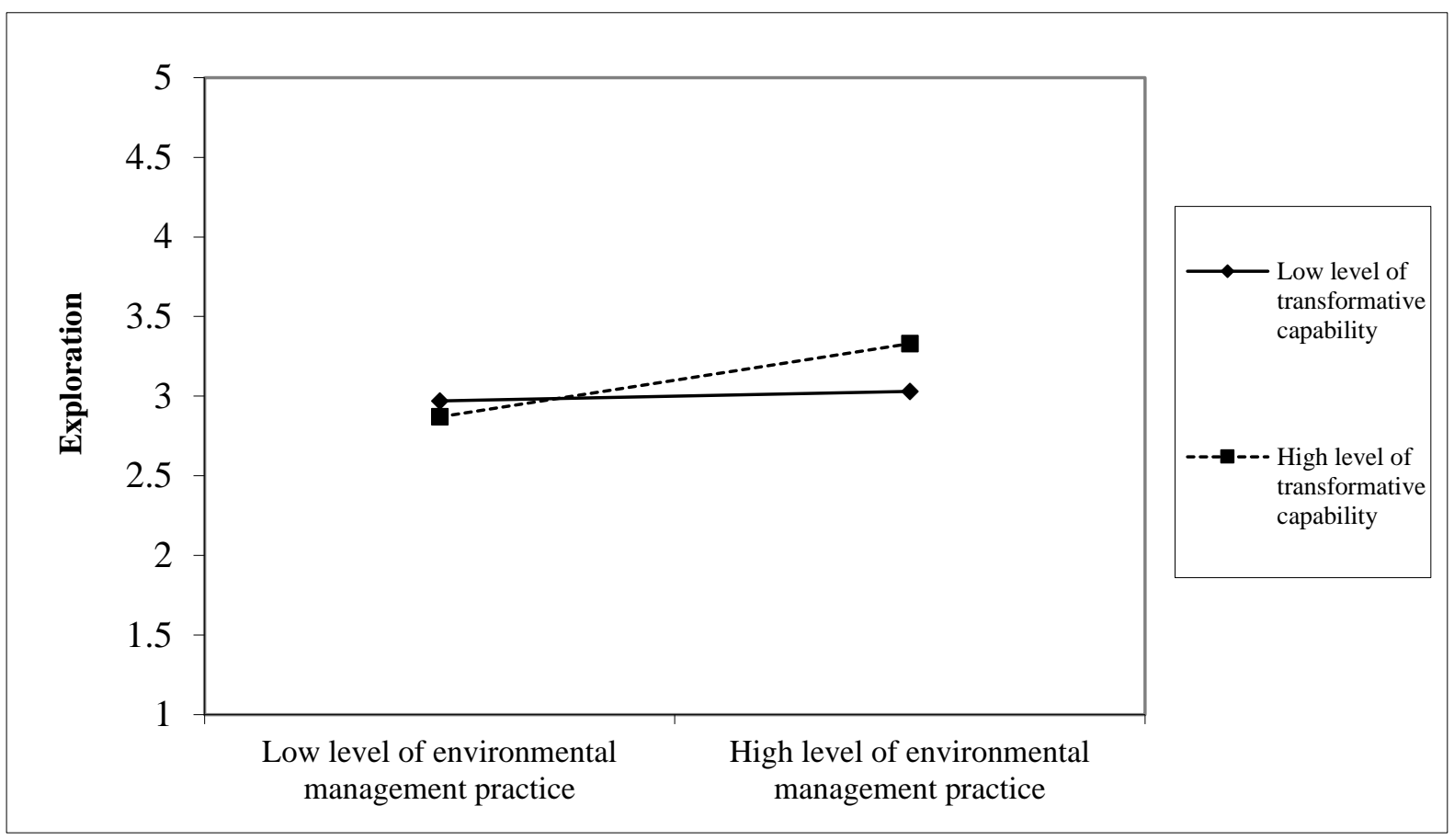

Panel A: Product Exploration = environmental management $\mathrm{x}$ absorptive capability

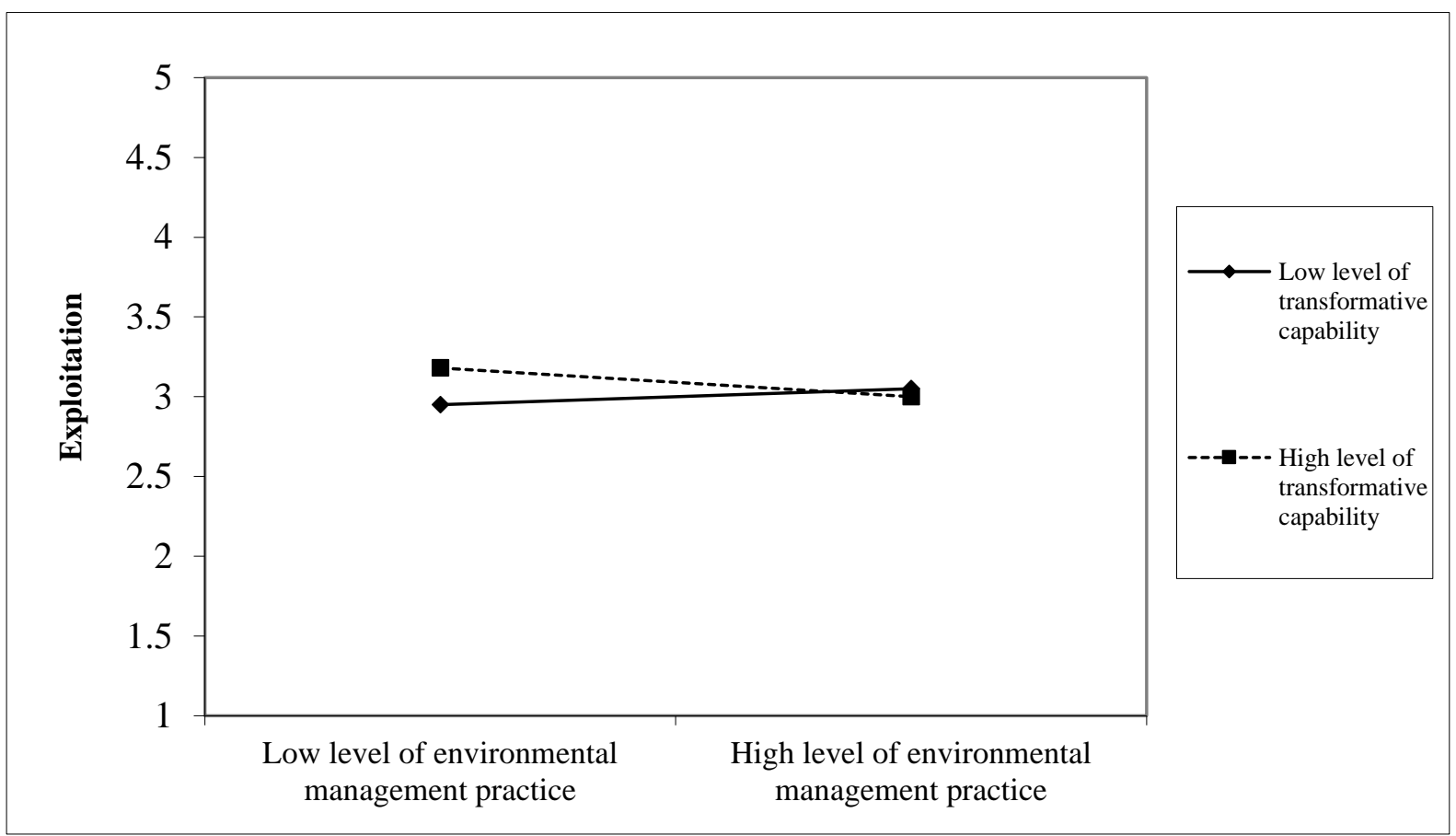




\section{Conclusion and discussion}

Business has been seeing a critical shift in that sustainability and environmental management are now top priorities on many firms' agenda with the intention of maintaining a cleaner production process. Practices aimed at conserving the environment have penetrated at a deeper level of organisations, from production and operational to innovation management, supporting pollution prevention and waste (Aragón-Correa and Sharma, 2003; Triguero et al., 2013). Following the current trend in the literature, this study's aim was to examine the role of environmental management and dynamic capability on product exploration and exploitation in the context of small manufacturing firms. The summary of findings is shown in Table 5. This study found that environmental management practice has a positive impact on product exploration and product exploitation $(\mathrm{Hl} a$ and $\mathrm{Hlb}$ ) which is in line with recent findings from the literature on environmental management and sustainability (e.g. Papagiannakis et al., 2019; Masri and Jaaron, 2017; De Medeiros et al., 2014; Azman et al., 2013). As there is increasing pressure to consider environment and sustainability aspects in business, small manufacturing firms are now keen to adapt their products to create cleaner production and more efficient use of resources such as energy, water and human capital. This would therefore result in an improved product or a new product that consumes fewer materials, uses sustainable materials, reduces waste and energy, and decreases the inflow of raw material inputs and water (Ribeiro Massote and Moura Santi, 2013).

Moreover, the study also found that dynamic capabilities matter and their role has been confirmed in numerous recent studies (e.g. Jiang et al., 2018; Zhou et al., 2018). Furthermore, it allows firms to leverage available resources and knowledge to update and exploit product innovation in response to changing business environments (Qiu et al., 2020). For product exploration, the alignment between environmental management and transformative capability 
produces a significant and positive impact on product exploration while environmental management and absorptive capability have a significant but negative impact on product exploitation. Generally, most of the literature suggests dynamic capabilities are a strong predictor for environmental management practices among firms (Arend, 2014). However, in this study, we find that different types of dynamic capability (transformative or absorptive capability) can have different impacts depending on a firm's external or internal conditions.

Table 5. Summary of Findings

\begin{tabular}{lcl}
\hline Hypothesis & $\begin{array}{c}\text { Proposed } \\
\text { Effects }\end{array}$ & $\begin{array}{c}\text { Hypothesis } \\
\text { Supported? }\end{array}$ \\
\hline H1a: EM $\rightarrow$ Product exploration & + & Yes* \\
H1b: EM $\rightarrow$ Product exploitation & + & Yes* $^{*}$ \\
H2a: EM Transformative capability $\rightarrow$ Product exploration & + & Yes** \\
H2b: EM*Transformative capability $\rightarrow$ Product exploitation & + & No \\
H3a: EM*Absorptive capability $\rightarrow$ Product exploration & + & No \\
H3b: EM*Absorptive capability $\rightarrow$ Product exploitation & + & No** \\
\hline
\end{tabular}
$* \mathrm{p}<0.05 ; * * \mathrm{p}<0.01$

These findings warrant further discussion. The interaction between environmental management and transformative capability $(\mathrm{H} 2 \mathrm{a})$ produces a significant and positive effect on product exploration while the same interaction has a positive but insignificant effect on product exploitation $(H 2 b)$. Apparently, the capability to utilise internal resources is more effective during exploration than during exploitation activities. While on average, our samples showed that most firms are engaged with the product exploitation process $(\overline{\mathrm{x}}=5.52)$, firms engaging in environmental management might not be dependent on internal sources of knowledge or information to aid them with the exploitation strategy. On the other hand, firms combine their internal knowledge, expertise and resources to explore opportunities in the product or market as a result of implementing environmental management. 
Furthermore, our results failed to confirm the role of absorptive capability $(H 3 a)$ as a moderator for an environmental management-product exploration relationship. In most cases, absorptive capability enables firms to adapt to changes in strategy to remain competitive (Winter, 2003). However, in the context of implementing environmental management during product exploration, internal resources and knowledge might be sufficient to assist firms during the product development process. Another explanation is because the small manufacturing firms in our sample come from diverse sectors where context and domestic spillover effect of environmental management might have different impacts. For instance, knowledge about environmental innovation in the chemical industry cannot be applied in the textile industry. This finding supports previous studies such as from Braun et al. (2010) that found the importance of absorptive capacity in capturing the domestic spillover effect in the case of wind and solar technology. In their study, it was evident that domestic spillovers have more significant impacts than international spillovers. In other word, knowledge about applying environmental management in product innovation requires contextual understanding.

Lastly, the study found that absorptive capability negatively moderates the relationship between environmental management and product exploitation $(H 3 b)$. This means that having a high level of absorptive capability together with practising environmental management will result in lower engagement with product exploitation. The possible explanation is because the engagement with external networks forces firms to focus more on product exploration rather than product exploitation. In this case, the potential returns as a result of developing a new product or new market is higher than exploiting a current product or market. This finding is in line with earlier studies (e.g. Arbolino et al., 2018) that while environmental management in product innovation may produce a positive effect on the environment, it can weaken firms' productivity performance. Pacheco et al. (2018) who looked into the moderating role of 
absorptive capability towards organisational factors on green innovation performance, finds this capability leads to new green products but not refinement of existing products. Moreover, the negative effect of absorptive capability might also be caused by some level of negative spillovers. In this case, the success of implementing environmental management during product innovation in one sector is associated with a decline in another (Truelove et al., 2014). It might be the case that firms have introduced environmental management practices in their product innovation process as a result of copying others' strategy without fully understanding the impact on their product, market and organisation.

\subsection{Contributions of the study}

The findings of this study suggest several theoretical implications. First, the findings add to the emerging stream of literature on environmental management. Previous studies focused on linking environmental management to general issues of product development (e.g. Sihvonen and Partanen, 2016) without specifying the type of activity during the product development process. This study extends Maletič et al's $(2016 ; 2018)$ work in studying the impact of environmental management on exploration and exploitation activities. Our study contributes to the development of knowledge in this subject by investigating the role of dynamic capability towards environmental management and innovation management (product exploration and product exploitation).

Second, we focus on a different perspective on the measurement of environmental management. Unlike previous work (e.g. Burgos-Jiménez et al., 2013), this study defines environmental management as Porter's (1985) value chain. The framework developed in this study can be adapted to other contexts or industries. This functional-based measure was established to view environmental management from another viewpoint besides activity- 
oriented measures. By reflecting on environmental management from a different functional level, this study looks to overcome the common problem of latent variables as having nonobservable items (Vidal-Salazar et al., 2012) which contributes towards having a more precise measurement of environmental management.

Third, this study adds more understanding regarding the role of dynamic capabilities. Limited empirical research has ventured into environmental management, especially among small manufacturing firms. We followed the work of Wang et al. (2015) that identified dynamic capability across firms (through a reflective construct approach). The importance of dynamic capability has been addressed over the past few years where several researchers have highlighted that specific knowledge capabilities are crucial to enhancing a firm's environmental practice since they connect to internal and external drivers (Melander, 2018; Hashim et al., 2015) The findings of this study show the unique characteristic of absorptive and transformative capability that has different impacts on the relationship between environmental management and innovation management. Thus, while agreeing to the positive potential of firm resources, there are some attributes that may lead the implemented strategy to reduced efficiency and effectiveness (Barney, 1991). To some extent, this study provides empirical evidence of the impact of spillovers in the context of environmental management and innovation. As recent studies (e.g. Aldieri et al., 2019; Truelove et al., 2014) have started to open the debate regarding the positive and negative impact of spillovers, this study shows that in adapting and practicing environmental management, especially in the context of product innovation, the role of locality and sectoral dimension should be considered. In this case, firms need to develop capability not only in acquiring and integrating internal and external knowledge but also adapting it to their own context. 
In addition to their theoretical contribution, the findings offer insights and practical recommendations. First, the results suggest that environmental management plays an important role in understanding product innovation among small manufacturing firms. Moreover, they further explain why environmental management should be prioritised among the selection of firm strategies. Second, the negative association between environmental management, absorptive capability and product exploitation reported in this study signals that small manufacturing firms wishing to pursue superior performance in product exploration through environmental management need to avoid engagement with absorptive capabilities. This finding is in line with the ideas from Maijanen and Virta (2017) that associate operational capability with incremental innovations and dynamic capability with radical innovations.

\subsection{Limitation and recommendation for further study}

The limitations of this study offer avenues for future research. First, the sample was limited only to manufacturers categorised as small manufacturing firms which limits the generalisability of the findings. Therefore, future work could focus on medium or large firms to compare with this study. In addition, we included all sectors within the manufacturing industry, such as metal, chemical, food, etc., and so neglected the possibility that different sectors might have their own approach leading to different findings. Further study can examine the practice of environmental management in each sector. Besides that, studies that specify the sector type would be useful since there are numerous sectors in the manufacturing industry with various characteristics. Second, we tested the hypothesis by means of a questionnaire thus providing cross-sectional data, which is limited to evaluating variables at different stages of firm development. The older firms may accumulate knowledge and experience to adapt to environmental management practice better than young firms. Therefore, future research could be longitudinal and designed to investigate environmental management, dynamic and product 
innovation at firms of different ages. Third, we gathered data using perception-based measures where surveys were answered by a single respondent representing the views of the sampled firm. We appreciate there could be potential bias and/or inaccurate reporting in answering the questionnaire. Future research could consider using secondary data as a replacement for the existing measures to counter this issue. Fourth, not all of our significant results scored a great statistical significance of less than 0.001. Since research on statistical significance has evolved, our concern towards lack of reproducibility for claims of new discoveries has grown, signalling that a lower threshold for statistical significance is needed. Following Benjamin et al. (2018), we recommend that hypothesis $3 \mathrm{~b}$ which has a statistical significance lower than 0.005 should be supported with further evidence based on future research.

\section{Appendix}

Appendix 1 Scale Items Used in Survey

\section{Scale Items}

\section{Environmental management}

To what extent has your firm engaged in voluntary environmental activities with:

Inbound logistics

Operations

Outbound logistics

Marketing and sales

Services

\section{Absorptive capability}

How did your firm adapt to newly acquired knowledge from outside the firm?

Our firm had the necessary skills to implement newly acquired knowledge

Our firm had the competences to transform the newly acquired knowledge

Our firm had the competences to use the newly acquired knowledge

Our firm had a clear division of roles and responsibilities for acquiring new knowledge

\section{Transformative capability}

How did your firm adapt knowledge gained from within the firm?

Our firm encouraged its personnel to challenge outmoded practices

Our firm evolved rapidly in response to shifts in our business priorities

Our firm was flexible enough to allow us to respond quickly to changes in our markets 
Our firm established its identity in order to be competitive in the open market

Our firm sought to determine areas of internal synergy

\section{Product Exploration}

Our firm has accepted demands that go beyond existing products and services Our firm has invented new products and services

Our firm has experimented with new products and services in our local market

Our firm has commercialized products and services that were completely new to our organization

\section{Product Exploitation}

Our firm has frequently refined the provision of existing products and services

Our firm has regularly implemented small adaptations to existing products and services

Our firm has introduced improved iterations of existing products and services for our local market

Our firm has improved the efficiency of our provision of products and services

\section{References}

Açikgöz, A., Günsel, A., Kuzey, C., Seçgin, G., 2016. Functional diversity, absorptive capability and product success: The moderating role of project complexity in new product development teams. Creat. Innov. Manag. 25, 90-108.

Aiken, L.S., West, S.G., Reno, R.R., 1991. Multiple regression: Testing and interpreting interactions, Sage, Newbury Park, CA.

Albino, V., Dangelico, R.M., Pontrandolfo, P., 2012. Do inter-organizational collaborations enhance a firm's environmental performance? A study of the largest U.S. companies. J. Clean. Prod. 37, 304-315.

Aldieri, L., Carlucci, F., Vinci, C.P., Yigitcanlar, T., 2019. Environmental innovation, knowledge spillovers and policy implications: A systematic review of the economic effects literature. J. Clean. Prod. 239, 118051.

Ambec, S., Lanoie, P., 2008. Does it pay to be green? A systematic overview. Acad. Manag. Perspect. 22, 45-62.

Aragón-Correa, J.A., Sharma, S., 2003. A contingent resource-based view of proactive corporate environmental strategy. Acad. Manag. Rev. 28, 71-88.

Arbolino, R., De Simone, L., Carlucci, F., Yigitcanlar, T., Ioppolo, G., 2018. Towards a sustainable industrial ecology: Implementation of a novel approach in the performance evaluation of Italian regions. J. Clean. Prod. 178, 220-236.

Arend, R.J., 2014. Social and environmental performance at SMEs: considering motivations, capabilities and instrumentalism. J. Bus. Ethics 125, 541-561.

Ateş, M.A., Bloemhof, J., Van Raaij, E.M., Wynstra, F., 2012. Proactive environmental strategy in a supply chain context: The mediating role of investments. Int. J. Prod. Res. 50, 1079-1095.

Azman, A., D’Silva, J.L., Samah, B.A., Man, N., Shaffril, H.A.M., 2013. Relationship between attitude, knowledge and support towards the acceptance of sustainable agriculture among contract farmers in Malaysia. Asian Soc. Sci. 9, 99-105.

Barney, J., 1991. Firm resources and sustained competitive advantage. J. Manage. 17, 99- 
120.

Benjamin, D.J., Berger, J.O., Johannesson, M., Nosek, B.A., Wagenmakers, E.J., Berk, R., Bollen, K.A., Brembs, B., Brown, L., Camerer, C., Cesarini, D., Chambers, C.D., Clyde, M., Cook, T.D., De Boeck, P., Dienes, Z., Dreber, A., Easwaran, K., Efferson, C., Fehr, E., Fidler, F., Field, A.P., Forster, M., George, E.I., Gonzalez, R., Goodman, S., Green, E., Green, D.P., Greenwald, A.G., Hadfield, J.D., Hedges, L. V., Held, L., Hua Ho, T., Hoijtink, H., Hruschka, D.J., Imai, K., Imbens, G., Ioannidis, J.P.A., Jeon, M., Jones, J.H., Kirchler, M., Laibson, D., List, J., Little, R., Lupia, A., Machery, E., Maxwell, S.E., McCarthy, M., Moore, D.A., Morgan, S.L., Munafó, M., Nakagawa, S., Nyhan, B., Parker, T.H., Pericchi, L., Perugini, M., Rouder, J., Rousseau, J., Savalei, V., Schönbrodt, F.D., Sellke, T., Sinclair, B., Tingley, D., Van Zandt, T., Vazire, S., Watts, D.J., Winship, C., Wolpert, R.L., Xie, Y., Young, C., Zinman, J., Johnson, V.E., 2018. Redefine statistical significance. Nat. Hum. Behav. 2, 6-10.

Bercovitz, J., Feldman, M., 2011. The mechanisms of collaboration in inventive teams: Composition, social networks and geography. Res. Policy 40, 81-93.

Beylot, A., Secchi, M., Cerutti, A., Merciai, S., Schmidt, J., Sala, S., 2019. Assessing the environmental impacts of EU consumption at macro-scale. J. Clean. Prod. 216, 382393.

Blackman, A., 2006. Small firms and the environment in developing countries: Collective impacts, collective action. Washington, DC: Resources for the Future Press.

Boiral, O., Guillaumie, L., Heras-Saizarbitoria, I., Tayo Tene, C.V., 2018. Adoption and outcomes of ISO 14001: A systematic review. Int. J. Manag. Rev. 20, 411-432.

Braun, F.G., Schmidt-Ehmcke, J., Zloczysti, P., 2010. Innovative Activity in Wind and Solar Technology: Empirical Evidence on Knowledge Spillovers Using Patent Data [WWW Document]. SSRN Electron. J. URL https://papers.ssrn.com/sol3/papers.cfm?abstract_id=1640387

Bromiley, P., Rau, D., 2016. Operations management and the resource based view: Another view. J. Oper. Manag. 41, 95-106.

Carbonell, P., Rodríguez-Escudero, A.I., Pujari, D., 2009. Customer involvement in new service development: An examination of antecedents and outcomes. J. Prod. Innov. Manag. 26, 536-550.

Chan, H.K., Yee, R.W.Y., Dai, J., Lim, M.K., 2016. The moderating effect of environmental dynamism on green product innovation and performance. Int. J. Prod. Econ. 181, 384391.

Chen, J., Chen, Y., Vanhaverbeke, W., 2011. The influence of scope, depth, and orientation of external technology sources on the innovative performance of Chinese firms.

Technovation 31, 362-373.

Chen, Y., 2011. Green organizational identity: sources and consequence. Manag. Decis. 49, 384-404.

Chen, Y.S., Chang, C.H., 2013. The determinants of green product development performance: Green dynamic capabilities, green transformational leadership, and green creativity. J. Bus. Ethics 116, 107-119.

Chen, Y.S., Chang, C.H., 2012. Enhance green purchase intentions: The roles of green perceived value, green perceived risk, and green trust. Manag. Decis. 50, 502-520.

Cohen, W.M., Levinthal, D.A., 1990. Absorptive capacity: A new perspective on learning and innovation. Adm. Sci. Q. 35, 128.

Dangelico, R.M., Pujari, D., Pontrandolfo, P., 2017. Green product innovation in manufacturing firms: A sustainability-oriented dynamic capability perspective. Bus. Strateg. Environ. 26, 490-506.

De Burgos-Jiménez, J., Vázquez-Brust, D., Plaza-Úbeda, J.A., Dijkshoorn, J., 2013. 
Environmental protection and financial performance : An empirical analysis in Wales. Int. J. Oper. Prod. Manag. 33, 981-1018.

De Medeiros, J.F., Ribeiro, J.L.D., Cortimiglia, M.N., 2014. Success factors for environmentally sustainable product innovation: A systematic literature review. J. Clean. Prod. 65, 76-86.

Department for Business Innovation \& Skills, 2012. Mid-sized businesses [WWW Document]. URL https://www.gov.uk/government/collections/mid-sized-businesses (accessed 1.12.16).

Deutz, P., Mcguire, M., Neighbour, G., 2013. Eco-design practice in the context of a structured design process : An interdisciplinary empirical study of UK manufacturers. J. Clean. Prod. 39, 117-128.

Dibrell, C., Craig, J.B., Hansen, E.N., 2011. How managerial attitudes toward the natural environment affect market orientation and innovation. J. Bus. Res. 64, 401-407.

Diwekar, U.M., Shastri, Y.N., 2010. Green process design, green energy, and sustainability: A systems analysis perspective. Comput. Chem. Eng. 34, 1348-1355.

Dunlap, D., McDonough III, E.F., Mudambi, R., Swift, T., 2016. Making up is hard to do: Knowledge acquisition strategies and the nature of new product innovation. J. Prod. Innov. Manag. 33, 472-491.

Eisenhardt, K.M., Martin, J.A., 2000. Dynamic capabilities: What are they? Strateg. Manag. J. 21, 1105-1121.

Feng, T., Sun, L., Zhang, Y., 2010. The effects of customer and supplier involvement on competitive advantage: An empirical study in China. Ind. Mark. Manag. 39, 1384-1394.

Ferreras-Méndez, J.L., Fernández-Mesa, A., Alegre, J., 2016. The relationship between knowledge search strategies and absorptive capacity: A deeper look. Technovation 54, $48-61$.

Fornell, C., Larcker, D.F., 1981. Evaluating structural equation models with unobservable variables and measurment error. J. Mark. 18, 39-50.

Foss, N.J., Lyngsie, J., Zahra, S.A., 2013. The role of external knowledge sources and organizational design in the process of opportunity exploitation. Strateg. Manag. J. 34, 1453-1471.

García-Morales, V.J., Lloréns-Montes, F.J., Verdú-Jover, A.J., 2008. The effects of transformational leadership on organizational performance through knowledge and innovation. Br. J. Manag. 19, 299-319.

Garud, R., Nayyar, P.R., 1994. Transformative capacity: Continual structuring by intertemporal technology transfer. Strateg. Manag. J. 15, 365-385.

Gebauer, H., Worch, H., Truffer, B., 2012. Absorptive capacity, learning processes and combinative capabilities as determinants of strategic innovation. Eur. Manag. J. 30, 5773.

Gibson, C.B., Birkinshaw, J., 2004. The antecedents, consequences and mediating role of organizational ambidexterity. Acad. Manag. J. 47, 209-226.

Gualandris, J., Kalchschmidt, M., 2016. Developing environmental and social performance : the role of suppliers' sustainability and buyer - supplier trust. Int. J. Prod. Res. 54, 2470-2486.

Hair, J.F., Black, W.C., Babin, B.J., Anderson, R.E., 2006. Multivariate Data Analysis (6th ed.), Prentice Hall. Upper Saddle River.

Harrington, S.J., Guimaraes, T., 2005. Corporate culture, absorptive capacity and IT success. Inf. Organ. 15, 39-63.

Hashim, R., Bock, A.J., Cooper, S., 2015. The relationship between absorptive capacity and green innovation. Int. J. Soc. Behav. Educ. Econ. Bus. Ind. Eng. 9, 1049-1056.

Helfat, C.E., Winter, S.G., 2011. Untangling dynamic and operational capabilities: Strategy 
for the never-changing world. Strateg. Manag. J. 32, 1243-1250.

Horbach, J., Rammer, C., Rennings, K., 2012. Determinants of eco-innovations by type of environmental impact - The role of regulatory push/pull, technology push and market pull. Ecol. Econ. 78, 112-122.

Ikram, M., Zhou, P., Shah, S.A.A., Liu, G.Q., 2019. Do environmental management systems help improve corporate sustainable development? Evidence from manufacturing companies in Pakistan. J. Clean. Prod. 226, 628-641.

Jabbour, A.B.L. de S., Jabbour, C.J.C., Latan, H., Teixeira, A.A., De Oliveira, J.H.C., 2014. Quality management, environmental management maturity, green supply chain practices and green performance of Brazilian companies with ISO 14001 certification: Direct and indirect effects. Transp. Res. Part E Logist. Transp. Rev. 67, 39-51.

Jansen, J.J.P., Bosch, F.A.J. Van Den, Volberda, H.W., 2006. Exploratory innovation, exploitative innovation, and performance: Effects of organizational and environmental moderators. Manage. Sci. 52, 1661-1674.

Jiang, W., Chai, H., Shao, J., Feng, T., 2018. Green entrepreneurial orientation for enhancing firm performance: A dynamic capability perspective. J. Clean. Prod. 198, 1311-1323.

Kammerlander, N., Burger, D., Fust, A., Fueglistaller, U., 2015. Exploration and exploitation in established small and medium-sized enterprises: The effect of CEOs' regulatory focus. J. Bus. Ventur. 30, 582-602.

Lane, P.J., Koka, B.R., Pathak, S., 2006. The reification of absorptive capacity: A critical review and rejuvenation of the construct. Acad. Manag. Rev. 31, 833-863.

Lenox, M., King, A., Ehrenfeld, J., 2000. An assessment of design-for-environment practices in leading US electronics firms. Interfaces (Providence). 30, 83-94.

Levinthal, D.A., March, J.G., 1993. The myopia of learning. Strateg. Manag. J. 14, 95-112.

López-Gamero, M.D., Molina-Azorín, J.F., 2016. Environmental management and firm competitiveness: The joint analysis of external and internal elements. Long Range Plann. 49, 746-763.

Maijanen, P., Virta, S., 2017. Managing exploration and exploitation in a media organisation-A capability-based approach to ambidexterity. J. Media Bus. Stud. 14, 146-165.

Makower, J., 2009. Strategies for the green economy: opportunities and challenges in the new world of business, New York: McGraw-Hill.

Maletič, M., Maletič, D., Dahlgaard, J.J., Dahlgaard-Park, S.M., Gomišček, B., 2014. Sustainability exploration and sustainability exploitation: From a literature review towards a conceptual framework. J. Clean. Prod. 79, 182-194.

Maletič, M., Maletič, D., Gomišček, B., 2018. The role of contingency factors on the relationship between sustainability practices and organizational performance. J. Clean. Prod. 171, 423-433.

Maletič, M., Maletič, D., Gomišček, B., 2016. The impact of sustainability exploration and sustainability exploitation practices on the organisational performance: a cross-country comparison. J. Clean. Prod. 138, 158-169.

March, J.G., 1991. Exploration and exploitation in organizational learning. Organ. Sci. 2, 7187.

Masri, H.A., Jaaron, A.A.M., 2017. Assessing green human resources management practices in Palestinian manufacturing context: An empirical study. J. Clean. Prod. 143, 474-489.

Mattila, A.S., Enz, C.A., 2002. The role of emotions in service encounters. J. Serv. Res. 4, 268-277.

Melander, L., 2018. Customer and supplier collaboration in green product innovation: External and internal capabilities. Bus. Strateg. Environ. 27, 677-693.

Mitra, S., Datta, P.P., 2014. Adoption of green supply chain management practices and their 
impact on performance: An exploratory study of Indian manufacturing firms. Int. J. Prod. Res. 52, 2085-2107.

Mokhtar, N., Jusoh, R., Zulkifli, N., 2016. Corporate characteristics and environmental management accounting (EMA) implementation: Evidence from Malaysian public listed companies (PLCs). J. Clean. Prod. 136, 111-122.

Molina-Azorín, J.F., Claver-Cortés, E., López-Gamero, M.D., Tarí, J.J., 2009. Green management and financial performance: A literature review. Manag. Decis. 47, 10801100.

Molina-Castillo, F.J., Jimenez-Jimenez, D., Munuera-Aleman, J.L., 2011. Product competence exploitation and exploration strategies: The impact on new product performance through quality and innovativeness. Ind. Mark. Manag. 40, 1172-1182.

Montabon, F., Sroufe, R., Narasimhan, R., 2007. An examination of corporate reporting, environmental management practices and firm performance. J. Oper. Manag. 25, 9981014.

Nath, P., Ramanathan, R., 2016. Environmental management practices, environmental technology portfolio, and environmental commitment: A content analytic approach for UK manufacturing firm. Int. J. Prod. Econ. 171, 427-437.

Nunnally, J.C., Bernstein, I.H., 1994. Psychometric Theory, McGraw-Hill, New York.

O'Cass, A., Heirati, N., Ngo, L.V., 2014. Achieving new product success via the synchronization of exploration and exploitation across multiple levels and functional areas. Ind. Mark. Manag. 43, 862-872.

O'Donohue, W., Torugsa, N.A., 2016. The moderating effect of ' Green ' HRM on the association between proactive environmental management and financial performance in small firms. Int. J. Hum. Resour. Manag. 27, 239-261.

Ogbeibu, S., Emelifeonwu, J., Senadjki, A., Gaskin, J., Kaivo-oja, J., 2019. Technological turbulence and greening of team creativity, product innovation, and human resource management: Implications for sustainability. J. Clean. Prod. 244, 118703.

Pacheco, L.M., Alves, M.F.R., Liboni, L.B., 2018. Green absorptive capacity: A mediationmoderation model of knowledge for innovation. Bus. Strateg. Environ. 27, 1502-1513.

Pandza, K., Holt, R., 2007. Absorptive and transformative capacities in nanotechnology innovation systems. J. Eng. Technol. Manag. 24, 347-365.

Papagiannakis, G., Voudouris, I., Lioukas, S., Kassinis, G., 2019. Environmental management systems and environmental product innovation: The role of stakeholder engagement. Bus. Strateg. Environ. 28, 939-950.

Podsakoff, P.M., Organ, D.W., 1986. Self-reports in organizational research: Problems and prospects. J. Manage. 12, 531-544.

Porter, M.E., 1985. Competitive advantage: Creating and sustaining superior performance, New York.

Potts, T., 2010. The natural advantage of regions: Linking sustainability, innovation, and regional development in Australia. J. Clean. Prod. 18, 713-725.

Prajogo, D.I., 2016. The strategic fit between innovation strategies and business environment in delivering business performance. Int. J. Prod. Econ. 171, 241-249.

Prajogo, D.I., Tang, A.K.Y., Lai, K.H., 2014. The diffusion of environmental management system and its effect on environmental management practices. Int. J. Oper. Prod. Manag. 34, 565-585.

Pujari, D., Wright, G., Peattie, K., 2003. Green and competitive influences on environmental new product development performance. J. Bus. Res. 56, 657-671.

Qiu, L., Jie, X., Wang, Y., Zhao, M., 2020. Green product innovation, green dynamic capability, and competitive advantage: Evidence from Chinese manufacturing enterprises. Corp. Soc. Responsib. Environ. Manag. 27, 146-165. 
Ribeiro Massote, C.H., Moura Santi, A.M., 2013. Implementation of a cleaner production program in a Brazilian wooden furniture factory. J. Clean. Prod. 46, 89-97.

Salonen, A., Jaakkola, E., 2015. Firm boundary decisions in solution business: Examining internal vs. external resource integration. Ind. Mark. Manag. 51, 171-183.

Schilke, O., 2014. On the contingent value of dynamic capabilities for competitive advantage: The nonlinear moderating effect of environmental dynamism. Strateg. Manag. J. 35, 179-203.

Severo, E.A., de Guimarães, J.C.F., Dorion, E.C.H., 2017. Cleaner production and environmental management as sustainable product innovation antecedents: A survey in Brazilian industries. J. Clean. Prod. 142, 87-97.

Shin, D., Curtis, M., Huisingh, D., Zwetsloot, G.I., 2008. Development of a sustainability policy model for promoting cleaner production: A knowledge integration approach. J. Clean. Prod. 16, 1823-1837.

Sihvonen, S., Partanen, J., 2016. Implementing environmental considerations within product development practices: A survey on employees' perspectives. J. Clean. Prod. 125, 189203.

Stone, L.J., 2006. Limitations of cleaner production programmes as organisational change agents I. Achieving commitment and on-going improvement. J. Clean. Prod. 14, 1-14.

Story, V.M., Boso, N., Cadogan, J.W., 2015. The form of relationship between firm-level product innovativeness and new product performance in developed and emerging markets. J. Prod. Innov. Manag. 32, 45-64.

Swamidass, P.M., Kotha, S., 1998. Explaining manufacturing technology use, firm size and performance using a multidimensional view of technology. J. Oper. Manag. 17, 23-37.

Teece, D.J., 2016. Dynamic capabilities and entrepreneurial management in large organizations: Toward a theory of the (entrepreneurial) firm. Eur. Econ. Rev. 86, 202216.

Teece, D.J., 2007. Explicating dynamic capabilities: The nature and microfoundations of (sustainable) enterprise performance. Strateg. Manag. J. 28, 1319-1350.

Teece, D.J., Pisano, G., Shuen, A., 1997. Dynamic capabilities and strategic management. Strateg. Manag. J. 18, 509-533.

Triguero, A., Moreno-Mondéjar, L., Davia, M.A., 2013. Drivers of different types of ecoinnovation in European SMEs. Ecol. Econ. 92, 25-33.

Truelove, H.B., Carrico, A.R., Weber, E.U., Raimi, K.T., Vandenbergh, M.P., 2014. Positive and negative spillover of pro-environmental behavior: An integrative review and theoretical framework. Glob. Environ. Chang. 29, 127-138.

Van Hoof, B., Lyon, T.P., 2013. Cleaner production in small firms taking part in Mexico's sustainable supplier program. J. Clean. Prod. 41, 270-282.

Vidal-Salazar, M.D., Cordón-Pozo, E., Ferrón-vilchez, V., 2012. Human resource management and developing proactive environmental strategies: The influence of environmental training and organizational learning. Hum. Resour. Manage. 51, 905934.

Voss, G.B., Sirdeshmukh, D., Voss, Z.G., 2008. The effects of slack resources and environmental threat on product exploration and exploitation. Acad. Manag. J. 51, 147164.

Wang, C.L., Ahmed, P.K., 2007. Dynamic capabilities: A review and research agenda. Int. J. Manag. Rev. 9, 31-51.

Wang, C.L., Senaratne, C., Rafiq, M., 2015. Success traps, dynamic capabilities and firm performance. Br. J. Manag. 26, 26-44.

Wang, J., Xue, Y., Sun, X., Yang, J., 2019. Green learning orientation, green knowledge acquisition and ambidextrous green innovation. J. Clean. Prod. 250, 119475. 
West, J., Bogers, M., 2014. Leveraging external sources of innovation: A review of research on open innovation. J. Prod. Innov. Manag. 31, 814-831.

Winter, S.G., 2003. Understanding dynamic capabilities. Strateg. Manag. J. 24, 991-995.

Xie, X.M., Huo, J., Qi, G.Y., Zhu, K.X., 2016a. Green process innovation and financial performance in emerging economies: Moderating effects of absorptive capacity and green subsidies. IEEE Trans. Eng. Manag. 63, 101-112.

Xie, X.M., Zang, Z.P., Qi, G.Y., 2016b. Assessing the environmental management efficiency of manufacturing sectors: Evidence from emerging economies. J. Clean. Prod. 112, 1422-1431.

Yalcinkaya, G., Calantone, R.J., Griffith, D.A., 2007. An examination of exploration and exploitation capabilities: Implications for product innovation and market performance. $\mathrm{J}$. Int. Mark. 15, 63-93.

Yang, H., Zheng, Y., Zhao, X., 2014. Exploration or exploitation? Small firms' alliance strategies with large firms. Strateg. Manag. J. 35, 146-157.

Zhang, H., Wu, F., Cui, A.S., 2015. Balancing market exploration and market exploitation in product innovation: A contingency perspective. Int. J. Res. Mark. 32, 297-308.

Zhang, L., Wang, J., You, J., 2015. Consumer environmental awareness and channel coordination with two substitutable products. Eur. J. Oper. Res. 241, 63-73.

Zhou, Y., Hong, J., Zhu, K., Yang, Y., Zhao, D., 2018. Dynamic capability matters: Uncovering its fundamental role in decision making of environmental innovation. J. Clean. Prod. 177, 516-526. 